\title{
Analisis Penerapan Sistem dan Prosedur Pemungutan Pajak Hiburan di Kota Bitung
}

\author{
Chrysti D. Ponto ${ }^{1}$ \\ Herman Karamoy ${ }^{2}$ \\ Treesje Runtu ${ }^{3}$
}

Fakultas Ekonomi dan Bisnis Jurusan Akuntansi
Universitas Sam Ratulangi Manado
Email: ${ }^{1}$ chrystid.ponto@gmail.com
${ }^{2}$ hkaramoy@ yahoo.com
${ }^{3}$ truntu@ gmail.com

\begin{abstract}
Regional autonomy in Indonesia came into force on 1 January 2001. Regional Government Law 28 of 2009 on Regional Tax and Retribution, is set to be one source of revenue that comes from inside the area. Bitung is one of the autonomous regions. With the availability of a variety of entertainment, receipt Pemerintahpun revenue increase due to impose a tax on organizing entertainment such entertainment. The objective of this study is to determine the application of tax collection systems and procedures of entertainment in the city of Bitung. The object of research is the Regional Revenue Office Bitung. This type of research, namely, qualitative research and analysis method used is descriptive analysis method. The results showed that the systems and procedures for the collection of entertainment tax imposed by the Regional Revenue Office Bitung as the tax authorities have been implemented properly, because in accordance with the Regional Regulation No. 1 in 2013, Mayor Regulation No. 21 in 2013, and Regulation No. 13 Year 2006. Regional Revenue Office Bitung City should continue to maintain the systems and procedures in accordance with the entertainment tax collection regulations.
\end{abstract}

Keywords: entertainment tax, system and procedure

\section{PENDAHULUAN}

Dalam rangka meningkatkan kemampuan keuangan daerah agar dapat melaksanakan otonomi khususnya yang berasal dari pajak daerah dan retribusi daerah, Pemerintah menetapkan berbagai kebijakan perpajakan daerah, diantaranya dengan menetapkan UU No.28 Tahun 2009 tentang Pajak Daerah dan Retribusi Daerah sebagaimana telah diubah beberapa kali atas UU No.34 Tahun 2000 dan UU No.18 Tahun 1997. Didalam UU No.28 Tahun 2009, pajak daerah dan retribusi daerah menjadi salah satu sumber pendapatan daerah yang penting guna membiayai pelaksanaan pemerintahan daerah sehingga terdapat perluasan objek pajak daerah dan retribusi daerah serta adanya pemberian diskresi (keleluasaan) dalam penerapan tarif.Anggaran Penerimaan dan Belanja Negara (APBN) dari tahun ke tahun, senantiasa memberikan tugas kepada Direktorat Jendral Pajak untuk menaikkan penerimaan pajak kepada negara. Tindakan tersebut sangat rasional, karena pada kenyataannya ratio antara jumlah wajib pajak dengan jumlah penduduk serta jumlah 
usaha masih sangat kecil, dan disamping itu, tahun-tahun yang akan datang pajak akan diproyeksikan menjadi salah satu pilar utama penerimaan negara secara mandiri.

Padatanggal 1 Januari Tahun 2001, otonomi daerah mulai diberlakukan di Indonesia. Dengan adanya otonomi daerah dipacu untuk dapat berkreasi mencari sumber penerimaan daerah yang dapat mendukung pembiayaan pengeluaran daerah. Agar dapat melaksanakan otonomi daerah, terdapat berbagai alternative sumber penerimaan yang dapat menjadi Pendapatan Asli Daerah (PAD). Pendapatan asli daerah (PAD) adalah pendapatan yang bersumber dan dipungut sendiri oleh pemerintah daerah. Sumber PAD terdiri dari pajak daerah, retribusi daerah, laba dari badan usaha milik daerah (BUMD), dan pendapatan asli daerah lainnya yang sah. Undang-undang No.33 Tahun 2004 tentang perimbangan keuangan antara pemerintah pusat dan pemerintah daerah pasal 1 ayat 18 menyebutkan bahwa, PAD adalah pendapatan yang diperoleh daerah yang dipungut berdasarkan peraturan daerah. Yang menjadi sumber-sumber PAD adalah pajak daerah, retribusi daerah, hasil pengeolaan kekayaan daerah yang dipisahkan dan lain-lain PAD yang sah.

Sistem yang digunakan dalam pemungutan pajak daerah secara umum adalah system self assessment dan official assessment. Hal ini dapat dilihat pada ketentuan UndangUndang No. 34 Tahun 2000 yang menentukan bahwa pajak dipungut berdasarkan penetapan kepala daerah atau dibayar sendiri oleh wajib pajak. Dalam pelaksanaannya, pemungutan pajak daerah tidak dapat diserahkan kepada pihak ketiga.

Peraturan reformasi keuangan daerah saat ini menegaskan informasi keuangan dapat dikumpulkan melalui sistem dan prosedur yang harus diikuti oleh pemerintah. Seluruh kegiatan operasional yang ada pada perusahaan memiliki standart sistem dan prosedur yang ditetapkan untuk mencapai tujuan dan sasaran.sistem dan prosedur administrasi pemungutan pajak hiburan yang diterapkan dengan baik akan memberikan kontribusi yang baik bagi peningkatan pendapatan asli daerah kota bitung.

\section{Tujuan Penelitian}

Tujuan dilaksanakannya penelitian ini yaitu untuk menganalisis penerapan sistem dan prosedur pemungutan pajak hiburan dikota bitung.

\section{TINJAUAN PUSTAKA Akuntansi Perpajakan}

Agoes dan Trisnawati (2010 : 7-8) menyatakanAkuntansi yang diterapkan sesuai dengan peraturan perpajakan disebut akuntansi pajak. Akuntans pajak merupakan bagian dari akuntansi komersial. Akuntansi pajak tidak memiliki standar seperti akuntansi komersial yang diatur dalam Standar Akuntansi Keuangan (SAK). Akuntansi pajak hanya digunakan untuk mencatat transaksi yang berhubungan dengan perpajakan. Dengan adanya akuntansi pajak, wajib pajak dapat dengan lebih mudah menyusun SPT.

\section{Fungsi Akuntansi Perpajakan}

Djoko Muljono (2013) menyatakan fungsi akuntansi pajak adalah mengolah data kuantitatif untuk menyajikan laporan keuangan yang memuat perhitungan perpajakan yang kemudian akan digunakan sebagai pertimbangan pengambilan keputusan. Tujuan kualitatif dalam akuntansi pajak adalah relevan, dapat dimengerti, daya uji, netral, tepat waktu, daya banding dan lengkap. Akuntansi pajak juga berfungsi mengolah data kuantitatif yang akan digunakan untuk menyajikan laporan keuangan yang memuat perhitungan perpajakan, yang akan digunakan untuk menyajikan keputusan.

\section{Pajak}

Rochmat Soemitro dalam Waluyo (2013: 1) menyatakan: Pajak adalah iuran kepada kas negara berdasarkan undang-undang (yang dapat dipaksakan) dengan tidak mendapat jasa timbal (kontraprestasi), yang langsung dapat ditunjukkan dan digunakan untuk membayar pengeluaran umum.Menurut P. J. A. Adriani dalam Waluyo (2013) pajak adalah 
iuran kepada negara (yang dapar dipaksakan) yang terutang oleh yang wajib membayaranya menurut peraturan-peraturan, dengan tidak mendapat prestasi kembali, yang langsung dapat ditunjuk, dan yang gunanya adalah untuk membiayai pengeluaranpengeluaran umum berhubung dengan tugas negara yang menyelenggarakan pemerintahan.

\section{Fungsi Pajak}

Mardiasmo (2011: 1) mengatakan fungsi pajak yaitu:

1. Fungsi budgetair merupakan fungsi utama pajak, atau fungsi fiskal (fiscal function), yaitu pajak sebagai sumber dana bagi pemerintah untuk membiayai pengeluaranpengeluarannya.

2. Fungsi RegulerendPajak sebagai alat untuk mengukur atau melaksanakan kebijaksanaan pemerintah dalam bidang sosial dan ekonomi.

\section{Syarat pemungutan pajak}

Mardiasmo (2011:2) menyatakanagar pemungutan pajak tidak menimbulkan hambatan atau perlawanan, maka pemungutan pajak harus memenuhi syarat sebagai berikut:

1. Pemungutan Pajak Harus Adil ( Syarat Keadilan )

2. Pemungutan Pajak Harus Berdasarkan Undang Undang ( Syarat Yuridis )

3. Tidak Mengganggu Perekonomian ( Syarat Ekonomis ).

4. Pemungutan Pajak Harus Efisien ( Syarat Finansiil )

5. Sistem Pemungutan Pajak Harus Sederhana

\section{Pengelompokan Pajak}

Jenis-jenis pajak dapat dikelompokkan sebagai berikut :

1. Pengelompokan pajak menurut golongannya, yaitu pajak langsung dan pajak tidak langsung.

2. Pengelompokan pajak menurut sifatnya, yaitu pajak subyektif dan pajak obyektif

3. Pengelompokan pajak menurut lembaga pemungutnya, yaitu pajak pusat (negara) dan pajak daerah

\section{Tata Cara Pemungutan Pajak}

\section{Stelsel Pajak}

Mardiasmo (2011:6) mengatakan dapat dilakukan berdasarkan 3 stelsel :

a. Stelsel nyata (riel stelsel)

Pengenaan pajak didasarkan pada objek (penghasilan yang nyata), sehingga pemungutannya baru dapat dilakukan pada akhir tahun pajak, yakni setelah penghasilan yang sesungguhnya diketahui.

b. Stelsel anggapan (fictieve stelsel)

Pengenaan pajak didasarkan pada suatu anggapan yang diatur oleh undang-undang. Misalnya, penghasilan satu tahun dianggap sama dengan tahun sebelumnya, sehingga pada awal tahun pajak sudah dapat ditetapkan besarnya pajak yang terutang untuk tahun pajak berjalan.

c. Stelsel Campuran

Stelsel ini merupakan kombinasi antara stelsel nyata dan stelsel anggapan. Pada awal tahun, besarnya pajak dihitung berdasarkan suatu anggapan, kemudian pada akhir tahun besarnya pajak disesuaikan dengan keadaan yang sebenaranya. Bila besarnya pajak menurut kenyataan lebih besar dari pajak menurut anggpan, maka Wajib Pajak harus menambah. Sebaliknya, jika lebih kecil kelebihannya dapat diminta kembali.

2. Asas Pemungutan Pajak

a. Asas domisili (asas tempat tinggal)

Negara berhak mengenakan pajak atas seluruh penghasilan Wajib Pajak yang bertempat tinggal di wilayahnya, baik penghasilan yang berasal dari dalam maupun dari luar negeri. Asas ini berlaku untuk Wajib Pajak dalam negeri.

b. Asas sumber 
Negara berhak mengenakan pajak atas penghasilan yang bersumber di wilayahnya tanpa memperhatikan tempat tinggal Wajib Pajak.

c. Asas kebangsaan

Pengenaan pajak dihubungkan dengan kebangsaan suatu negara.

3. Sistem Pemungutan Pajak

a. Official Assessment System

Adalah suatu sistem pemungutan yang memberi wewenang kepada pemerintah (fiskus) untuk menentukan besarnya pajak yang terutang oleh Wajib Pajak.

b. Self Assessment System

Adalah suatu sistem pemungutan pajak yang memberi wewenang kepada Wajib Pajak untuk menentukan sendiri besarnya pajak yang terutang.

c. With Holding System

Adalah suatu sistem pemungutan pajak yang memberi wewenang kepada pihak ketiga (bukan fiskus dan bukan Wajib Pajak yang bersaangkutan) untuk menentukan besarnya pajak yang terutang oleh Wajib Pajak.

\section{Pembagian Pajak Daerah}

Mardiasmo (2011: 13) mengatakan Pajak daerah dibagi menjadi dua bagian, yaitu:

1. Pajak Provinsi, terdiri dari berikut ini.

a. Pajak Kendaraan Bermotor

b. Bea Balik Nama Kendaraan Bermotor

c. Pajak Bahan Bakar Kendaraan Bermotor

d. Pajak Air Permukaan

e. Pajak Rokok

2. Pajak Kabupaten/Kota, terdiri dari berikut ini.

a. Pajak Hotel

b. Pajak Restoran

c. Pajak Hiburan

d. Pajak Reklame

e. Pajak Penerangan Jalan

f. Pajak Mineral Bukan Logam Dan Batuan

g. Pajak Parkir

h. Pajak Air Tanah

i. Pajak Sarang Burung Walet

j. Pajak Bumi Dan Bangunan (PBB)

k. Bea Perolehan Hak Atas Tanah Dan Bangunan (BPHTB)

\section{Sistem Pemungutan Pajak Daerah}

Ketentuan yang diatur dalam Undang-undang Ketentuan Umum dan Tata Cara Perpajakan Indonesia dengan jelas menentukan bahwa sistem perpajakan Indonesia menggunakan self assessment system. Hal ini telah diberlakukan sejak reformasi perpajakan di Indonesia tahun 1983. Penetapan system self assessment juga di anut dalam Undang-undang Nomor 18 Tahun 1997 dan Undang-undang Nomor 34 Tahun 2000. Karena karakteristik setiap jenis pajak daerah tidak sama, sistem ini tidak dapat diberlakukan untuk semua jenis pajak daerah. Pemungutan pajak daerah saat ini menggunakan tiga system pemungutan pajak, yaitu:

1. Dibayar sendiri oleh wajib pajak, sistem ini merupakan perwujudan dari sistemself assessment.

2. Ditetapkan oleh kepala daerah. Sistem ini merupakan perwujudan dari sistemofficial assessment.

3. Dipungut oleh pemungut pajak. Sistem ini merupakan perwujudan dari sistem with holding 
Secara umum, sistem yang digunakan dalam pemungutan pajak daerah, baik sistem self assessment dan official assessment. Tergantung pada jenis pajak daerah tersebut.

\section{Pajak Hiburan}

Sesuai dengan Undang-undang Nomor 28 Tahun 2009 Pasal 1 angka 24 dan25. Pajak hiburan adalah pajak atas penyelenggaraan hiburan. Sedangkan yang dimaksud dengan hiburan adalah semua jenis tontonan, pertunjukan, permainan, dan atau keramaian yang dinikmati dengan dipungut biaya.

\section{Dasar Hukum Pemungutan Pajak Hiburan}

Dasar hukum pemungutan pajak hiburan pada suatu Kabupaten atau Kota adalah Undang-undang Nomor 28 Tahun 2009 tentang Pajak Daerah dan Retribusi Daerah,Undang-undang Nomor 34 Tahun 2000 yang merupakan perubahan atas Undangundang No. 18 tahun 1997 tentang Pajak Daerah dan Retribusi Daerah, Peraturan Pemerintah Nomor 65 tahun 2001 tentang Pajak Daerah, Peraturan Daerah Nomor 1 Tahun 2013 atas perubahan Peraturan Daerah Nomor 8 tahun 2010 tentang Pajak Daerah, dan Keputusan Bupati/Walikota yang mengatur tentang Pajak Hiburan sebagai aturan pelaksana peraturan daerah tentang Pajak Hiburan pada kabupaten/kota dimaksud.

\section{Subjek dan Objek Pajak Hiburan}

Dalam Undang-undang No 28 Tahun 2009 tentang pajak daerah dan retribusi daerah pasal 43 disebutkan subjek pajak hiburan yaitu sebagai berikut.

1. Subjek pajak hiburan adalah orang pribadi atau Badan yan menikmati Hiburan.

2. Wajib Pajak hiburan adalah orang pribadi atau Badan yang menyelenggarakan hiburan.

Dalam Undang-undang No. 28 Tahun 2009 tentang pajak dan retribusi daerah Pasal 42 disebutkan sebagai berikut.

1. Objek pajak hiburan adalah jasa penyelenggaraan hiburan dengan dipungut bayaran.

2. Hiburan tersebut sebagaimana dimaksud pada ayat (1) adalah tontonan film, pagelaran kesenian, musik, tari, dan/atau busana, kontes kecantikan, binaraga, Pameran, diskotik, karaoke, klab malam, sirkus, akrobat, dan sulap, permainan bilyard, golf dan bowling, Pacuan kuda, kendaraan bermotor, dan permainan ketangkasan, panti pijat, refleksi, mandi uap/spa, dan pusat kebugaran (fitness center), pertandingan olahraga.

3. Penyelenggaraan Hiburan sebagaimana dimaksud pada ayat (2) dapat dikecualikan dengan Peraturan Daerah.

\section{Masa Pajak, Tahun Pajak, saat Terutang Pajak, dan Wilayah Pemungutan Pajak Hiburan}

Pada pajak hiburan, masa pajak merupakan jangka waktu yang lamanya sama dengan satu bulan takwim atau jangka waktu lain yang ditetapkan dengan keputusan bupati/walikota. Dalam pengertian masa pajak bagian dari bulan dihitung satu bulan penuh. Tahun pajak adalah jangka waktu yang lamanya satu tahun takwim, kecuali apabila wajib pajak menggunakan tahun buku yang tidak sama dengan tahun takwim.

Pajak yang terutang merupakan pajak hiburan yang harus dibayarkan oleh wajib pajak pada suatu saat, dalam masa pajak, atau dalam tahun pajak menurut ketentuan peraturan daerah tentang pajak hiburan yang ditetapkan oleh pemerintah daerah kabupaten/kota setempat. Saat pajak terutang dalam masa pajak terjadi pada saat penyelenggaraan hiburan. Jika pembayaran diterima penyelenggara hiburan sebelum hiburan diselenggarakan, pajak hiburan terutang dalam masa pajak terjadi pada saat pembayaran.

Pajak hiburan yang terutang dipungut di wilayah kabupaten/kota tempat hiburan diselenggarakan. Hal ini terkait dengan kewenangan pemerintah kabupaten/kota yang hanya terbatas atas setiap tempat hiburan yang berlokasi dan terdaftar dalam lingkup wilayah administrasinya. 


\section{Penelitian Terdahulu}

Utari (2012) dengan judul analisis Sistem dan prosedur pemungutan pajak hiburan pada dinas pendapatan daerah kota pontianak. Tujuan penelitian untuk mengetahui sistemdan prosedur pemungutan pajak hiburan yang dilaksanakan DISPENDA Kota Pontianak dan untuk mengetahui tingkat efektivitas dari pemungutan pajak hiburan serta untuk mengetahui kontribusi dari pajak hiburan terhadap PAD. Metode analisis yang digunakan Analisis Flowchart. Hasil penelitian menunjukkan bahwa Sistem dan prosedur pemungutan pajak hiburan yang dilaksanakan oleh Dinas Pendapatan Daerah Kota Pontianak telah sesuai dengan peraturan daerah No. 11 tahun 2005 dan pengendalian internal yang dilaksanakan sudah cukup baik.

Lumentah (2013) dengan judul analisis penerapan sistem pemungutan pajak hiburan di kota manado. Tujuan penelitian untuk mengetahui sistem pemungutan pajak hiburan di kota manado. Metode analisis yang digunakan adalah analisis deskriptif. Hasil penelitian menunjukkan bahwa Sistem pemungutan pajak hiburan di kota manado telah sesuai dengan peraturan daerah yang ada yaitu Peraturan Daerah kota Manado N0. 2 Tahun 2011.

\section{METODE PENELITIAN}

\section{Jenis Penelitian}

Penelitian ini menggunakan jenis metode penelitian kualitatif dengan melakukan pengkajian data dalam bentuk deskriptif atau berbentuk uraian. Sugiyono (2014:8)metode penelitian kualitatif adalah metode penlitian yang berlandaskan pada filsafat postpositivisme, dimana peneliti adalah sebagai instrumen kunci, pengumpulan data dilakukan secara triangulasi (gabungan) dan analisis data bersifat induktif.

\section{Tempat dan Waktu Penelitian}

Tempat di Kantor Dinas Pendapatan Daerah (DISPENDA) KotaBitung selaku instansi pelaksana pemungutan pajak hiburan. Dan waktu penelitian ini dilakukan selama bulan september 2015.

\section{Prosedur Penelitian}

Langkah - langkah yang digunakan dalam memecahkan permasalahan penelitian ini adalah dengan tahap-tahap sebagai berikut:

1. Memasukkan surat permohonan penelitian dengan persetujuan dari Fakultas Ekonomi dan Bisnis untuk Penelitian pada objek-objek yang akan dipakai dalam penyusunan skripsi ini

2. Mengumpulkan data pendukung peneliti yang akan digunakan dalam penyusunan skripsi ini.

3. Melakukan analisis data untuk membahas masalah dengan menjelaskan suatu keadaan sesuai dengan judul penelitian tersebut.

4. setelah semua data penelitian telah diperoleh maka akan di buat kesimpulan dan saran.

\section{Metode Pengumpulan Data}

Metode yang digunakan dalam pengumpulan data-data dalam penelitian adalalah Penelitian Lapangan (Field Research). Penelitian ini adalah penelitian yang langsung dilakukan pada organisi atau objek yang bersangkutan, dimana yang diambil sebagian besar diperoleh dengan teknik sebagai berikut :

a. Dokumentasi, teknik pengumpulan data melalui dokumentasi untuk memperoleh data dan informasi berupa catatan tertulis/gambar yang tersimpan berkaitan dengan masalah yang diteliti

b. Wawancara, tanya jawab secara langsung dengan pihak-pihak yang bertanggung jawab dengan masalah-masalah yang diteliti 


\section{Metode Analisis}

Metode Analisis data yang digunakan dalam penelitian ini adalah menggunakan metode analisis deskriptif.Analisis deskriptif adalah analisis yang diwujudkan dengan cara menggambarkan kenyataan atau keadaan-keadaan atas suatu objek dalam bentuk uraian kalimat, data angka berdasarkan keterangan-keterangan dari pihak-pihak yang berhubungan langsung dengan penelitian ini. Hasil analisis tersebut kemudian diinterpretasikan guna memberikan gambaran yang jelas terhadap permasalahan yang diajukan.

\section{HASIL PENELITIAN DAN PEMBAHASAN}

\subsection{Hasil Penelitian}

\section{Tarif Pajak Hiburan}

Tarif Pajak Hiburan yang dikenakan di Kota Bitung ditetapkan berdasarkan Peraturan Daerah Kota Bitung No. 1 Tahun 2013. Tarif pajak Hiburan adalah sebagai berikut :

1. Tarif Pajak Hiburan ditetapkan sebesar $20 \%$

2. Pegelaran busana tarif pajak sebesar $25 \%$

3. Kontes kecantikan tarif pajak sebesar $25 \%$

4. Diskotik tarif pajak sebesar $30 \%$

5. Karaoke tarif pajak sebesar $25 \%$

6. Klub Malam tarif pajak sebesar $35 \%$

7. Permainan ketangkasan tarif pajak hiburan ditetapkan sebesar $50 \%$

8. Panti pijat tarif pajak sebesar $30 \%$

9. Mandi uap/spa tarif pajak sebesar $30 \%$

10. kesenian rakyat/tradisional dikenakan tarif pajak sebesar $10 \%$.

\section{Perhitungan Pajak Hiburan}

Peraturan Daerah Kota Bitung No.1 Tahun 2013 menyatakan, besaran pokok Pajak Hiburan yang terutang dihitung dengan cara mengalikan tarif pajak dengan dasar pengenaan pajak. Perhitungan Pajak Hiburan adalah :

Pajak Terutang $=\quad$ Tarif pajak $\mathrm{x}$ Dasar Pengenaan Pajak

$=\quad$ Tarif pajak $\mathrm{x}$ Jumlah Uang yang Diterima atau

yang Seharusnya Diterima oleh PenyelenggaraHiburan

\section{Sistem dan Prosedur Pemungutan Pajak di Dispenda Bitung}

1. Pendaftaran Objek Pajak Baru

a. Mengisi formulir pendaftaran dengan jelas, benar dan lengkap.

b. Formulir pendaftaran disediakan dan diperoleh secara gratis di Dinas Pendapatan Daerah Kota Bitung.

c. Wajib pajak yang belum memiliki Nomor Pokok Wajib Pajak Daerah (NPWPD), akan diterbitkan setelah selesai mengisi formulir pendaftaran

d. Formulir pendaftaran ditandatangani oleh wajib pajak, jika bukan ditanda tangani oleh wajib pajak, harus dilampiri dengan surat kuasa.

e. Pendaftaran objek pajak disampaikan kepada walikota paling lambat 30 hari terhitung sejak dimulainya usaha oleh wajib pajak

f. Melampirkan dokumen pendukung meliputi :

- Fotokopi kartu tanda penduduk atau identitas diri lainnya

- Fotokopi bukti kepemilikan/ surat kontrak/pemanfaatan tanah (sertifikat/akta jual beli/dokumen lain yang sejenis).

- Fotokopi izin menjalankan usaha (akte perusahaan/SIUP/dokumen lain yang sejenis).

2. Pendataan Objek Pajak 
a. Pendataan objek pajak dilakukan di Dinas Pendapatan Daerah dengan menuangkan hasilnya dalam formulir pendaftaran.

b. Pendataan objek pajak dilakukan dengan cara sebagai berikut :

- Penyampaian dari wajib pajak dan pemantauan di lapangan

- Identifikasi wajib pajak

- Verifikasi data objek pajak

3. Penerbitan SPTPD/SKPD/SKPDKB/SKPDKBT/SKPDLB/STPD

a. SKPD/SKPDKB/STPD ditetapkan, diterbitkan dan ditanda tangani oleh Walikota atau pejabat yang ditunjuk.

b. SPTPD ditandatangani oleh wajib pajak, karena SPTPD adalah surat yang digunakan oleh wajib pajak untuk melaporkan penghitungan dan/atau pembayaran pajak.

4. Pembayaran Pajak dan angsuran

a. Pajak yang terutang berdasarkan SKPD/SKPDKB/STPD terutang harus dilunasi paling lambat 1 bulan sejak tanggal ditetapkan Surat Ketetapan Pajak oleh Dinas Pendapatan Daerah.

b. Pajak yang terutang dapat dibayar ke kas daerah melalui bank atau tempat lain yang ditetapkan oleh walikota.

c. Pembayaran pajak dapat dilakukan secara langsung ke tempat pembayaran yang ditunjuk yang tercantum dalam SPTPD/SKPD/STPD.

d. Pembayaran dengan cek bank/bilyet giro bank, akan dianggap sah apabila telah dilakukan kliring

e. Wajib pajak menerima STTS sebagai bukti telah melunasi pembayaran dari Bank atau tempat lain yang ditunjuk oleh walikota.

f. Wajib pajak berkewajiban mengirimkan dan/atau melaporkan STTS kepada Dinas Pendapatan Daerah sebagai bukti pelunasan pajak.

g. Pengangsuran diberikan atas permohonan wajib pajak yang disampaikan secara tertulis yang ditujukan ke Dinas Pendapatan Daerah. Dengan lampiran sebagai berikut :

- Surat permohonan pengangsuran.

- Fotokopi identitas wajib pajak atau kuasa wajib pajak.

- Bukti SKPD/SKPDKB/STPD sebagai pemberitahuan pajak terutang.

h. Pembayaran pengangsuran pajak terutang harus dilunasi sesuai dengan masa yang sudah ditetapkan oleh Dinas Pendapatan Daerah paling lama 3 kali masa angsuran.

i. Pajak yang terutang yang pada saat jatuh tempo pembayaran tidak dibayar atau kurang dibayar, dikenakan denda administrasi sebesar $2 \%$ sebulan yang dihitung dari saat jatuh tempo sampai dengan hari pembayaran untuk jangka waktu paling lama 24 bulan.

j. Sanksi administrasi 25\% dikenakan apabila wajib pajak tidak mngisi dan melaporkan SPTPD yang seharusnya dilakukan oleh wajib pajak.

5. Penghapusan atau Pengurangan sanksi Administrasi dan Pembetulan atau Pembatalan SPTPD, SKPD, SKPDKB, SKPDLB dan STPD yang tidak benar

Walikota atau pejabat yang ditunjuk karena jabatan, berdasarkan permohonan wajib pajak dapat :

a. Mengurangkan atau menghapuskan sanksi administrasi yang dikenakan karena kekeliruan.

b. Permohonan dan pengurangan sanksi administrasi di lampiri dengan.

- Surat permohonan pengurangan

- Fotokopi identitas wajib pajak

- Bukti SKPD/SKPDKB/STPD sebagai pemberitahuan penetapan pajak terutang. 
- Dokumen pendukung yang dapat menujukkan bahwa denda administrasi dikenakan bukan karena kekhilafan wajib pajak atau bukan karena kesalahan wajib pajak

c. Membetulkan dan membatalkan SPTPD, SKPD, SKPDKB atau STPD yang tidak benar.

d. Untuk mendukung permohonan pembetulan, maka dilampri dengan.

- Surat permohonan pembetulan SKPD, SKPDKB, STPD

- Fotokopi identitas wajib pajak

- Dokumen pendukung yang dapat menunjukkan bahwa SKPD, SKPDKb, STPD tidak benar.

e. Persyaratan Permohonan pembatalan SKPD/SKPDKB/ STPD meliputi:

- Mengajukan permohonan pembatalan

- Surat pernyataan dari pemohon dan sebab pembatalan dengan bermaterai.

- Fotokopi identitas diri wajib pajak

- Bukti SKPD/SKPDKB/STPD sebagai pemberitahuan penetapan pajak terutang.

6. Pengurangan Pajak

Pengurangan pajak dapat diberikan kepada wajib pajak karena:

a. Kondisi tertentu seperti untuk orang pribadi adalah objek pajak yang penghasilannya rendah dan untuk badan adalah ketika mengalami kerugian dan kesulitan likuiditas pada tahun sebelumnya sehingga tidak dapat memenuhi kewajiban.

b. Sebab-sebab tertentu misalnya, ketika objek pajak terkena bencana alam atau sebab lain yang luar biasa.

c. Pengurangan diberikan kepada wajib pajak atas penetapan terutang yang tercantum dalam SKPD, SKPDKB atau STPD. Untuk kondisi tertentu dapat diberikan pengurangan sebesar paling tinggi $75 \%$ dari pajak yang terutang dan untuk sebab tertentu sebesar paling tinggi 100\%. Pajak terutang yang tercantum dalam SKPD, SKPDKB atau STPD adalah pokok pajak ditambah dengan sanksi adminitrasi. Untuk SKPD, SKPDKB atau STPD yang sudah mendapat pengurangan tidak dapat dimintakan pengurangan atas sanksi administrasinya.

d. Permohonan yang diajukan secara perseorangan harus memenuhi persyaratan :

- Satu permohonan untuk satu SKPD, SKPDKB atau STPD.

- Diajukan secara tertulis dalam Bahasa Indonesia dengan mencantumkan besarnya permohonan pengurangan kepada Kepala Dinas.

- Melampirkan SKPD, SKPDKB atau STPD

- Di tandatangani oleh wajib pajak

- Diajukan dalam waktu 10 hari sejak diterimanya SKPD, SKPDKB atau STPD.

- Tidak mempunyai tunggakan atas pajak pada bulan atau tahun sebelumnya.

7. Kompensasi Pajak Terutang

Atas dasar kelebihan pembayaran Pajak Terutang, wajib pajak dapat mengajukan permohonan kompensasi dari kelebihan pembayaran untuk pembayaran masa pajak pada bulan berikutnya.Pengajuan permohonan kompensasi harus disertai dengan alasan yang jelas dan melengkapi persyaratan sebagai berikut :

a. SKPD, SKPDKB atau STPD sebagai pemberitahuan pajak terutang

b. Bukti pelunasan bank atas pajak terutang

c. Surat kuasa dalam hal dikuasakan

d. Fotokopi identitas wajib pajak

e. Surat permohonan kompensasi

8. Penghapusan piutang pajak yang sudah kadaluwarsa

Tata cara penghapusan piutang pajak yang sudah kadaluwarsa adalah sebagai berikut : 
a. Kepala Dinas mengusulkan kepada walikota nama-nama wajib pajak yang akan dihapuskan piutangnya.

b. Walikota menetapkan keputusan pengapusan piutang pajak yang sudah kadaluwarsa sesuai ketentuan perundang-undangan.

c. Keputusan yang dimaksud memuat nama, objek, subjek, jumlah penetapan dan masa pajak.

9. Pembukuan, Pemeriksaan dan Pengawasan

Tata cara pembukuan, pemeriksaan dan pengawasan adalah sebagai berikut :

a. Wajib pajak mendirikan usahanya dengan modal paling sedikit Rp 150.000 .000

b. Pejabat yang berwenang melakukan pemeriksaan pajak daerah dengan tujuan untuk menguji kepatuhan pemenuhan kewajiban perpajakan daerah dalam rangka melaksanakan ketentuan peraturan perundang-undangan perpajakan daerah.

c. Pemeriksaaan dapat dilakukan dengan pemeriksaan berkas atau pemeriksaan lapangan

Pemeriksaaan dapat dilakukan dalam hal :

a. Untuk menguji kepatuhan pemenuhan kewajiban perpajakan daerah.

b. Mendapat indikasi wajib pajak tidak melaporkan kewajiban pajak dengan benar

c. Terdapat data kewajiban pajak yang belum dilunasi pada beberapa waktu sebelumnya

d. Wajib pajak mengajukan permohonan pengurangan, menunda pembayaran kewajiban pajak.

\section{SIMDA Pendapatan}

Dalam pemungutan pajak hiburan dispenda bitung telah menggunakan bantuan aplikasi komputer SIMDA Pendapatan yang didisain berdasarkan sistem informasi pengelolaan keuangan daerah dan telah sesuai dengan peraturan perundang-undangan yang berlaku. dengan tujuan sebagai sarana optimalisasi pajak/retribusi daerah serta agar pemerintah daerah dapat menghasilkan laporan-laporan pengelolaan pendapatan dan piutang sebagai dokumen pendukung laporan keuangan pemerintah daerah.

\section{Realisasi Pajak Hiburan}

Tingkat efektivitas pajak hiburan terhadap Pendapatan Asli Daerah Kota Bitung tahun 2011 sebesar 60,98\% dengan kriteria cukup efektif, tahun 2012 sebesar 132,52\% dengan kriteria sangat efektif , tahun 2013 sebesar $175,01 \% \%$ dengan kriteria sangat efektif, tahun 2014 sebesar 69,08\% dengan kriteria cukup efektif. untuk realisasi pajak hiburan yang terendah berada ditahun 2011, sedangkan untuk realisasi pajak hiburan tertinggi berada ditahun 2013.

\subsection{Pembahasan}

\section{Tarif Pajak Hiburan}

Pemungutan tarif Pajak Hiburan yang dilaksanakan oleh Dinas Pendapatan Daerah Kota Bitung, telah sesuai dengan Peraturan Daerah Kota Bitung No. 1 Tahun 2013.

\section{Perhitungan Pajak Hiburan}

Perhitungan pajak hiburan yang dilakukan oleh Dinas Pendapatan Daerah Kota Bitung telah sesuai dengan perhitungan pajak daerah yang ditetapkan walikota Bitung dalam peraturan Daerah Kota Bitung No. 1 Tahun 2013.

\section{Sistem dan Prosedur Pemungutan Pajak Hiburan di Dinas Pendapatan Daerah Kota Bitung}

Sistem pemungutan pajak yang digunakan oleh DISPENDA kota bitung adalah sistem self assessment dimana wajib pajak yang melaporkan, menghitung, dan membayar sendiri kewajiban pajaknya. Meskipun Dinas Pendapatan Daerah telah menggunakan aplikasi komputer SIMDA Pendapatan yang membantu dalam prosedur pemungutan pajak daerah, namun dalam pelaksanaannya tetap menggunakan sistem self assessment. Serta prosedur 
administrasi pemungutan pajak hiburan yang dilaksanakan di Kota Bitung telah sesuai dengan Peraturan Walikota No 21 Tahun 2013 mengenai Ketentuan Pelaksanaan Pemungutan Pajak Daerah di Kota Bitung dan Peraturan Daerah No. 1 Tahun 2013 tentang Pajak Daerah dan Retribusi Daerah.

Adapun prosedur pengangsuran utang pajak yang dilaksankan di Dinas Pendapatan Daerah Kota Bitung telah sesuai dengan peraturan yang ada, dimana wajib pajak yang mendapat keringanan adalah wajib pajak yang memiliki tunggakan pajak dan tidak sanggup untuk melunasi sekaligus. Meskipun demikian wajib pajak tetap harus membayar pajak bulanannya secara rutin.

Untuk prosedur keberatan dan banding yang di ajukan oleh wajib pajak tidak akan dilayani oleh Dinas Pendapatan Daerah karena sistem pemungutan pajak hiburan dilakukan dengan self assessment. Dimana wajib pajak berwenang untuk menghitung, menyetor dan melaporkan sendiri kewajiban pajaknya sehingga tidak etis apabila wajib pajak keberatan atas utang pajaknya.

Dinas Pendapatan Daerah juga tidak akan melaksanakan prosedur Pembetulan, Pembatalan, pengurangan dan penghapusan atau pengurangan sanksi administrasi untuk Wajib Pajak yang menggunakan self assessment karena tidak adanya kegiatan keberatan dan banding. Dinas Pendapatan Daerah Kota Bitung tidak akan memberikan pelayanan untuk prosedur Kompensasi Pajak Terutang bagi wajib pajak yang menggunakan sistem self assessment,karena tidak dilaksanakannya prosedur Pembetulan, Pembatalan, Pengurangan dan penghapusan atau pengurangan sanksi.

\section{SIMDA Pendapatan}

Sejak tahun 2013 dinas pendapatan daerah kota bitung mulai menggunakan sistem informasi manajemen daerah (SIMDA) khusunya SIMDA Pendapatan yang dirasa bermanfaat untuk pemungutan pajak daerah. Namun demikian, para petugas yang menggunakan sistem ini merasa sistem ini lebih rumit dibandingkan dengan prosedur manual. Hal ini disebabkan dengan adanya perbedaan antara SIMDA dan Prosedur manual, seperti dalam SIMDA wajib pajak datang sendiri ke Dinas Pendapatan Daerah untuk melakukan kewajiban pajaknya dan dokumen-dokumen pendukung yang digunakan dalam prosedur administrasi pemungutan pajak dihasilkan langsung dari aplikasi SIMDA Pendapatan ini. Sedangkan untuk prosedur manual mengharuskan petugas Dinas Pendapatan Daerah untuk mengirimkan SPTPD kepada wajib pajak.

\section{Realisasi Pajak Hiburan}

Untuk realisasi pajak hiburan di kota bitung, Dinas Pendapatan Daerah mencatat untuk tahun 2011 pajak hiburan tidak mencapai targetdan untuk tahun 2012 mengalami kenaikanmelebihi dari target yang ditetapkan, dan kemudian di tahun 2013 pajak hiburan kembali mengalami kenaikan, namun pada tahun 2014 pajak hiburan mengalami penurunan kembali dari target yang ditetapkan.

\section{Analisis Sistem Pengendalian Internal}

\section{Lingkungan Pengendalian}

Dipenda Kota Bitung telah melaksanakan lingkungan pengendalian yang baik, hal ini dapat dilihat dari semua faktor lingkungan pengendalian diantaranya nilai-nilai integritas dan etika, struktur organisasi, komitmen terhadap kompetensi, pembagian kerja yang sudah terstruktur, pegawai yang sudah kompeten, filosofi kerja yang diberikan kepala dinas melalui visi, misi dinas, dan SDM yang sudah terlatih.

2. Penaksiran Resiko

Dipenda Kota Bitung telah melaksanakan Penaksiran Resiko dengan baik. Hal ini dapat dilihat dari adanya rencana dan strategi serta kebijakan yang ditetapkan salah satunya adalah penigkatan pemahaman masyarakat sadar pajak, dengan tujuan meningkatkan kemampuan masyarakat lokal dalam mendukung pembangunan Kota Bitung. 


\section{Aktivitas Pengendalian}

Dipenda Kota Bitung telah melaksanakan aktivitas pengendalian secara efektif, hal ini dapat dilihat dengan diterapkannya unsur-unsur aktivitas pengendalian yang meliputi otorisasi yang memadai, pemisahan tugas, dokumen dan catatan yang memadai, pengelolaan dan pemungutan pajak daerah khusunya pajak hiburan sepenuhnya dilakukan oleh DIPENDA kota Bitung, disertai dokumen dan catatan yang bernomor urut cetak salah satunya Surat Ketetapan Pajak Daerah (SKPD) sehingga hal ini mendukung jalannya sistem dan prosedur pemungutan pajak hiburan.

4. Informasi dan Komunikasi

DIPENDA kota Bitung telah menerapkan informasi yang mendukung pengendalian manajemen dan komunikasi yang efektif dalam memberi pemahaman yang jelas mengenai semua kebijakan prosedur yang terkait dengan pengendalian internal. Sistem informasi dan komunikasi diterapkan secara online yaitu dengan adanya sistem pengelolaan keuangan berbasis teknologi berupa Sistem Informasi Manajemen Daerah (SIMDA) Pendapatan. Sistem ini digunakan untuk melakukam serangkaian prosedur penerimaan dan pemungutan pajak serta untuk mendapatkan informasi mengenai wajib pajak yang sudah membayar dan belum melunasi pajak terutangnya.

5. Pengawasan

DIPENDA Kota Bitung melakukan pemantauan atau pengawasan untuk mengoptimalkan pemungutan pajak daerah lebih khususnya untuk pajak hiburan yang dilaksanakan oleh seksi pendataan, pendaftaran, penetapan, dan penagihan. Petugaspetugas tersebut diberikan tanggung jawab untuk memantau para wajib pajak dalam membayar pajak dengan tujuan untuk meningkatkan pendapatan daerah dan juga pengendalian internal pajak daerah

\section{PENUTUP}

\subsection{Kesimpulan}

Berdasarkanpenelitian yang dilakukanterhadap Sistem dan Prosedur yang dilakukan oleh Dinas Pendapatan Daerah Kota Bitung, makadapat ditarik kesimpulan sebagai berikut:

Sistem dan prosedur yang diterapkan untuk pemungutan pajak hiburan telah sesuai dengan peraturan yang ada yakni Peraturan Daerah No. 1 Tahun 2013 tentang Pajak Daerah dan Retribusi Daerah serta Peraturan Walikota No 21 Tahun 2013 mengenai Ketentuan Pelaksanaan Pemungutan Pajak Daerah di Kota Bitung. Kecuali untuk prosedur administrasi keberatan dan banding, Pembetulan, Pembatalan, Pengurangan dan penghapusan atau pengurangan sanksi administrasi serta kompensasi pajak terutang tidak dilaksanakan oleh Dinas Pendapatan Daerah Kota Bitung Karena Wajib Pajak menggunakan sistem self assessment.

\subsection{Saran}

Saran dalam penelitian ini adalah:

1. Dinas Pendapatan Daerah Kota Bitung dalam pemungutan pajak hiburan hendaknya terus mempertahankan sistem dan prosedur administrasi pemungutan pajak hiburan sesuai dengan peraturan yang berlaku.

2. Untuk penggunaan aplikasi SIMDA Pendapatan, pihak DISPENDA harus memberikan pelatihan serta sosialisasi lagi kepada karyawan agar aplikasi tersebut dapat dipahami dan dimengerti dengan baik.

3. DISPENDA kiranya lebih memperhatikan pembebanan tarif pajak hiburan agar wajib pajak tidak merasa terbebani sehingga kesadaran wajib pajak juga akan meningkat. Pemberian sanksi juga harus tepat agar dapat memberikan efek jera kepada wajib pajak yang melanggar atau bertindak curang dalam melaporkan, menghitung, dan menyetor kewajiban pajaknya. 
4. Sosialisasi terhadap pajak hiburan juga harus lebih ditingkatkan agar masyarakat yang telah memenuhi syarat sebagai wajib pajak hiburan dapat melaksanakan tanggung jawabnya dalam membayar pajak hiburan.

\section{DAFTAR PUSTAKA}

Agoes, Sukrisno dan Trisnawati. 2010. Akuntansi Perpajakan. Edisi 2 Revisi. Salemba Empat. Jakarta.

Lumentah, Yulia. 2013. Analisis Penerapan Sistem Pemungutan Pajak Hiburan di Kota Manado.Jurnal Emba. Universitas Sam Ratulangi. http://download.portalgaruda.org/article.php?article $=108998 \& v a l=1025$.

Diakses pada tanggal 15 juni 2015. Hal 1049-1059.

Mardiasmo, 2011. Perpajakan. Andi. Jakarta.

Muljono, Djoko.2010. Panduan Brevet Pajak: Akuntansi Pajak dan Ketentuan Umum Perpajakan. Andi. Yogyakarta.

Pemerintah Republik Indonesia, Peraturab Daerah No. 1 Tahun 2013, tentang. Pajak Daerah dan Retribusi Daerah. Bitung.

Pemerintah Republik Indonesia, Peraturan Walikota No 21 Tahun 2013 mengenai Ketentuan Pelaksanaan Pemungutan Pajak Daerah di Kota Bitung. Bitung.

Pemerintah Republik Indonesia. 2011. Undang-Undang No.28 Tahun 2009 tentang. Pajak Daerah dan Retribusi Daerah, Jakarta.

Sugiyono. 2014.Metode Penelitian Kuantitatif, Kualitatif dan R\&D.Alfabeta. Bandung.

Utin, Tri, Utari. 2012.Analisis Sistem dan Prosedur Pemungutan Pajak Hiburan pada Dinas Pendapatan Daerah

Kota Pontianak.Http://Jurnal.untan.ac.id/index.php/ejafe/article/view/1260. Diakses Juli,10, 2015.

Waluyo. 2013. Perpajakan Indonesia.Salemba Empat. Jakarta. 